\title{
Collaborative Networks Strategies of Transportation Systems with RFID: A Case Study For a Depot of Empty Containers
}

\author{
Washington Luiz Pereira Soares \\ Universidade Católica de Santos \\ Santos, Brazil \\ Hamilton Pozo \\ SCEETEPS - Fatec Rubens Lara \\ Santos, Brazil \\ Getulio Kazue Akabane \\ CEETEPS - Fatec São Paulo \\ São Paulo, Brazil
}

\begin{abstract}
This paper proposes ways to reduce operating costs for a Depot of empty containers, mainly to avoid wasting time with the separation of containers for cargo operations directed at offshore oil rigs. The methodology is exploratory and qualitative and looks at technological innovations such as Radio Frequency Identification (RFID). The technology is applicable in a depot of empty containers so that by using RFID solutions movements of containers on the backyard can better control the mobility and supply for critical situations such as offshore platforms that are located two hundred kilometers up the coastal port.
\end{abstract}

Keywords: RFID, Strategy, Technology, Cost reduction

\section{INTRODUCTION}

Technological innovations are organizational changes that depend on important tools in managing top performers as agents involved in cases, which are very important because they are driving development in various sectors. Understanding the effects of these changes by interactions in technological processes is necessary to discuss the positive interactions in relation to empirical foundation, which is investigated in a pragmatic way, without generalities, to be verified by theoretical correlations applicable mainly to the change process technology platform.

In a collaborative transportation system connected by various technologies, various management functions or interacting elements can occur, as well as numerous opportunities for better engagement of the parties involved in the business of technology innovation focused on business logistics. In this respect, for example, there are several guidelines being tested for modal transition in RFID data, with the goal of logistical service item products.

The technology of Radio Frequency Identification (RFID) is briefly composed of three parts: an antenna, a tag and a reader that operate within a transmission range of the radio, the frequency of which operates from about 15,000 to 1011 cycles per second. In other words, the RFID operates as a wireless technology that uses a frequency band of radio waves exclusively, as authorized by the regulatory agency in Brazil, ANATEL, and the National Telecommunications Agency, whose duties are techniques specific to the RFID system, which can be rewording. 
Once established in a transportation system, the system is able to read the RFID radio frequency identification and digital form, can establish communication with a data channel intranet where information can expand when linked, and give new instructions electronically using the intranet network or internet. In view of the diversity of businesses, a specific understanding of the differentiation of the systemic collaborative processes is needed, as well as for the transport systems of empty containers.

It is necessary to discover the effects of the relationship between supply and demand of RFID technology, which can in logistics, not fully meet all phases of the business, where the resources needed and the supplies chain flows vary between physical and digital virtual systems.

However, to expedite the businesses involved in the development of the supply chain, the new RFID interfaces that appeared were aimed only at the preliminary service data collection system and currently have debased other strategic perspectives. For example, one of the main strategic options for investments in P \& G - Oil and Gas in RFID, whereby it is hoped to associate data and control devices which rely on quick responses in order to organize inventories.

However, it is necessary to invest in advance technologies in order to detect specific supply capabilities, including understanding of inventory in the supply chain in the land beyond the sea. This is a critical situation because there are various forms of operational details of groceries, for example by expiration date, location, and availability of resources and geographical inter alia where the automated information is important and sometimes strategic. In order to generate eco-efficiency guidance, one can embed the RFID application in logistics, minimize supply errors with the best speed available, and incorporate the decision-making processes of the supply location, which involve the physical movement of products or fillers.

The situations analyzed and the associated case study proposed in this paper reveals the possibility of benchmarking distribution processes, with which RFID technology is applied to manage a stock of empty at depots which may assign the transport service of supplies to oil and gas platforms.

The study remains mainly restricted to operating assumptions, which may subsequently be directed to oil and gas developments in the study, where there is a lack of control over the ways of different types of inventories. However, the development of a management of empty containers depot of chain oil and gas in the organizational changes in the distribution of physical resources are very impactful in terms of space and separation platforms, for the inventory accuracy in the process of physical distribution of loads positioned in different locations.

The main goal of this understanding of the results is therefore to focus on minimizing errors in the depot logistics organization in relation to empty containers. Therefore, the study researches the best results of eco-efficiency, without the need for constant exchange of resources transferred mistakenly between areas, except to save time wasted in logistics, transportation or activities in relation to possible mistaken shifts of resources by operational failures given the scenario's complexity, which is geographically limited depending on whether the destination loads are platforms located offshore.

Therefore, the benefits of RFID data are expected in this circumstance to attract plenty of interest from suppliers of oil and gas chains seeking to better manage their inventories and 
assets, in critical situations. However, based on a single case study of developing a depot of empty containers in Brazil, it can be argued that the benefits of RFID tracking for real-time assets may exceed the benefits not fully identified by better inventory visibility.

In this work, we emphasize the ways to add value by using automated information collaboratively, which can be applied by service providers where there are agents or operators of logistics, with investments in RFID technology in the supply chain.

\section{REVIEW OF LITERATURE}

According to Gonçalves (2011) information guides decisions that give logic to the actions operating through telecommunications or highways, which are logistical resources in fundamental processes that involve greater complexity in an integrated manner across multiple systems or international operations.

In this case, the type of inter-organizational network design implemented into a transportation system can improve performance and facilitate the alignment of goals to strategic thinking, and can provide the suppliers involved more collaborative projects.

According to organizational priority, it can guide the focal point of the applicability of resources for various technical dimensions, even when attention is directed to a transport system.

In terms of rules of planning systems, the example of RFID remains directed at the possibility of transforming the processes of information flows and decision networks, to focus only on the second level proposed by Goncalves (2011).

From a technological standpoint, Machado, Vaz and Sacramento (2012) describe the automated readings to integrate RFID business processes managed by the ERP - Enterprise Resource Planning, WMS - Warehouse Management System, which among others, can be very complex given the diversity and quantity of devices of the volume of RFID data generated by a network of readers.

From a strategic standpoint, it is important to note that when the proposed innovation project involves a change in network technology platform, the application is directed to RFID, there will also be information sharing between trading partners regarding the assets within each step of the manufacturing process, storage and transportation in a supply chain.

Due to the complexity involved in the creation of a transportation system, a priori, it is important to investigate the links are aligned where new technological mechanisms have been replaced after mapping the flow of agents involved in the process of physical distribution of cargo for deploying RFID.

As in the Collaborative, Planning, Forecasting and Replenishment (CPFR) processes, the mapping strategy can avoid overlapping perspectives in interactive integration with RFID every step, item by product, or directly in the management process improvements to achieve operational results more economically.

The initial idea for the implementation of RFID chain involves a model of organizational CPFR management at points of data collection, radio frequency and technology that can be adjusted, 
per process, from cooperative systems that automate deliveries through the operational status of the products or dispersion of stocks by supplier locations.

In the model of collaborative management of suppliers with RFID is very important integrated the process control for physical distribution. The importance of mapping activities directed to collaborative management system requires quick responses from suppliers whose needs should be adjusted for collaborative processes with new technologies, as figure 1 below.

\begin{tabular}{|c|c|c|c|c|c|}
\hline $\begin{array}{l}\text { Programs } \\
\text { quick answers }\end{array}$ & $\begin{array}{l}\text { Acceptable } \\
\text { strategy }\end{array}$ & $\begin{array}{l}\text { Who } \\
\text { decides } \\
\text { replacemen }\end{array}$ & $\begin{array}{l}\text { How decides } \\
\text { to spare }\end{array}$ & $\begin{array}{l}\text { Propert } \\
\text { y stodks }\end{array}$ & $\begin{array}{l}\text { As the supplier } \\
\text { uses the data } \\
\text { demand }\end{array}$ \\
\hline $\begin{array}{l}\text { QR-Quick } \\
\text { Response }\end{array}$ & QR - Quick Response & Customer & $\begin{array}{l}\text { Fore cast sales } \\
\text { and vendor } \\
\text { independe nt. }\end{array}$ & Customer & $\begin{array}{l}\text { Improve Sales } \\
\text { Forecasting and } \\
\text { synchronization } \\
\text { operations. }\end{array}$ \\
\hline $\begin{array}{c}\text { CRP- } \\
\text { Continuous } \\
\text { Replenishment } \\
\text { Program }\end{array}$ & $\begin{array}{l}\text { CRP - Continuous } \\
\text { Replenishment } \\
\text { Program }\end{array}$ & Provider & $\begin{array}{l}\text { Based on the } \\
\text { position of the } \\
\text { stock The } \\
\text { replacement } \\
\text { Ievel is decided } \\
\text { jointly. }\end{array}$ & $\begin{array}{l}\text { Supplier / } \\
\text { austomer }\end{array}$ & $\begin{array}{l}\text { Update inventory } \\
\text { position and } \\
\text { modify } \\
\text { replacement level } \\
\text { in conjunction } \\
\text { with the reta i. }\end{array}$ \\
\hline $\begin{array}{l}\text { ECR - Efficient } \\
\text { Consumer } \\
\text { Res ponse }\end{array}$ & $\begin{array}{l}\text { ECR- Efficient } \\
\text { Consumer Response }\end{array}$ & Provider & $\begin{array}{l}\text { Based on the } \\
\text { position of the } \\
\text { stocks The } \\
\text { replace ment } \\
\text { level is decided } \\
\text { jointly. }\end{array}$ & $\begin{array}{l}\text { Supplier// } \\
\text { austomer }\end{array}$ & $\begin{array}{l}\text { Update inventory } \\
\text { position and } \\
\text { modify } \\
\text { replacement level } \\
\text { in conjunction } \\
\text { with the reta i. }\end{array}$ \\
\hline $\begin{array}{l}\text { CPFR- } \\
\text { Collaborative } \\
\text { Planning } \\
\text { Forecasting } \\
\text { and } \\
\text { Replenishme } \\
\text { nt }\end{array}$ & $\begin{array}{l}\text { Collabor at ive } \\
\text { Plamning, } \\
\text { For ecasting and } \\
\text { Replenishment }\end{array}$ & Provider & $\begin{array}{l}\text { Based on the } \\
\text { position of the } \\
\text { stock. The } \\
\text { replacement } \\
\text { level is decid ed } \\
\text { jointly. }\end{array}$ & $\begin{array}{l}\text { Supplier } \\
\text { customer }\end{array}$ & $\begin{array}{l}\text { Improve Sales } \\
\text { Forecasting and } \\
\text { synchronization } \\
\text { of poperations } \\
\text { with customer } \\
\text { participation. }\end{array}$ \\
\hline $\begin{array}{l}\text { VMII - Vendor } \\
\text { Managed } \\
\text { Irventory }\end{array}$ & $\begin{array}{l}\text { VMI - Vendor } \\
\text { Mana ged Inventory }\end{array}$ & Provider & $\begin{array}{l}\text { Based on } \\
\text { projected net } \\
\text { need. }\end{array}$ & $\begin{array}{l}\text { Supplier// } \\
\text { customer } \\
\text { or payral }\end{array}$ & $\begin{array}{l}\text { Genera te sales } \\
\text { forecast and } \\
\text { project need l iquid. }\end{array}$ \\
\hline JIT - II & Just in Timell & In - Plant & $\begin{array}{l}\text { According to the } \\
\text { decision support } \\
\text { system of the } \\
\text { dient. }\end{array}$ & $\begin{array}{l}\text { Supplier// } \\
\text { austomer }\end{array}$ & $\begin{array}{l}\text { Improve Sales } \\
\text { Forecasting and } \\
\text { synchronization } \\
\text { operations. }\end{array}$ \\
\hline A-CPFR-RFID & $\begin{array}{l}\text { Adjustment Planning } \\
\text { Forecasting a nd } \\
\text { Replenishmment } \\
\text { Collaborative /RFID. }\end{array}$ & On-Time & $\begin{array}{l}\text { System for real- } \\
\text { time location } \\
\text { (RT LS) with } \\
\text { exchange of } \\
\text { shared } \\
\text { resources on a } \\
\text { network. }\end{array}$ & $\begin{array}{l}\text { Supplier/ } \\
\text { customer } \\
\text { or lessee } \\
\text { or } \\
\text { consignee }\end{array}$ & $\begin{array}{l}\text { Cenera te sales } \\
\text { forecast and } \\
\text { project need I iquid. }\end{array}$ \\
\hline
\end{tabular}

Figure 1. Summary of Rapid Response Strategies (Wanke 2004 Source: Adapted by the author (Soares, 2012)

According to Wanke (2004) several customers and suppliers seek to cost-effectively redesign their product flow in manufacturing operations and distribution through improved information sharing. According to the author, during the last ten years these initiatives are often used in the literature rapid response programs (PRRs). The PRRs logistics services are grounded in cooperation and information sharing of customer demands of their supplier (Wanke, 2004).

The goal of deploying RFID at distribution points is therefore also to get quick answers about the needs of each actor terminal dedicated to platforms, offshore, particularly where it is critical supplies to generate velocity, however, the model form of CPFR is more collaborative.

Logistics management is that part of the supply chain that plans, implements and controls the efficient flows, forward and reverse, and storage of goods, services and information between the point of origin and point of consumption in order to meet the requirements of customers (CSMP, 2012). A priori, the RFID Journal LLC (2012, p.24) defines technology as RFID: Radio Frequency Identification, or any method of identifying unique items using radio frequency waves where the operating system of logistics management of retail, boils down to one reader also called interrogator communicates with a transponder, which holds digital information in a microchip or other resources strategically positioned in the links of the chain by forms of RFID tags applied to product control. To this end, the labels are used for specific material to reflect chipless or return information for a portion of radio waves transmitted during each event in a transportation system. 
In Brazil, associate technologies in logistics management CPFR model for data automation, RFID for example, are very significant changes in economic enterprises that use information systems for production control in the management of the supply chain. However, most Brazilian companies in the logistics management of transport systems do not usually apply RFID, except in the retail market, where, as a pioneer, RFID has been most commonly applied at points of sales.

The use of Information and Communication Technologies (ICT) is facilitating closer collaboration and promoting a new approach of supply chain transparency. The use of an ICT framework based on intelligent multi-agents allows the integration of different supply chain strategies with the stocks and transportation reduction. Many companies identify the best suppliers of services and products to meet their needs and help drive down costs with integrating and automating all components of their logistics process.

A lot of Investments on RFID technology help to leverage reliable and timely RFID, according Chao et al., (2007). The Supply Chain Management optimal demand and logistics execution. The RFID solutions are designed to facilitate the gathering usage and storage of RFID data. It has been observed that the use of RFID technologies will enable a framework for enterprises to collaborate, plan monitor and execute, while optimally adapt in real- time to operate under unplanned occurrences in the extended supply chain

The organizational changes of the VICS CPFR (2012) involve norms and this organ first defines CPFR not only a technological tool, but also a practice management system or business that gathers intelligence various companies in the planning and care of customer demands. The standardization of fact arises from rules imposed by VICS in 2010, where the aims is for automation through RFID data to corroborate management systems for collecting and forecasting supply, which should occur in the case of retail, from the POS in real time.

CPFR (2012) describes the collaborative management model, which relies on technology, so there may be specific tools for example RFID, as there may be generic tools for electronic data exchange. According to CPFR (2012), the supply chain management encompasses the planning and management of all activities involved in sourcing and procurement activities developed for a particular purpose.

Van (2005) argues that with the practice of management, the prospects of procurement should be understood as all the activities required in order to get a vendor's product to its final destination, encompasses the purchasing function, stores, transit and transportation; arrival inspections, quality control and assurance, making companies select suppliers using the TCO or Total Cost Ownership and not just the price of feedstock or raw material.

The CPFR concept underscores the accession of new automation technologies to RFID procurement where the aim is to control the process interface products supply by suppliers per item of supply. It is with this understanding that one develops more collaborative logistics as there is data transparency and a concomitant need for constant investment in the transport system (VICS, 2012).

Some researchers argue that RFID is an evolution of the bar code, which allows the identification of products without human interference and can replace the activities that are currently performed with scanning bar codes. In the case of the intelligent RFID tag, there is a microchip that can be affixed to each item, thus tracing such products throughout the chain, 
radio frequency and bounded function of the type of supply, by picking up signals a transponder.

Another advantage of RFID smart labels can be seen as an advantage in the application and if the item/product is dirty, wet or otherwise damaged the RFID does not impede the reading, which does not happen with the example of the control of management by code bar. This is possible because RFID tags are read by radio waves rather than optical means (again, RFID does not require "line of sight"). The reading speed is less than 100 milliseconds, even in extreme temperatures or obstructed. Another unique feature of the RFID option is called "kill", in which an RFID tagged item is disabled, for example, when a user exits a department of an environment or a transportation system.

Stanczak (2007) compared the operational aspect of the UPC operations of the RFID; the reader reads an RFID tag as, and for example, a scanner reads a UPC code. Unlike the UPC code reader, RFID tags do not require what is called a "line of sight"; they do not require the optical reader tags. Another advantage is that RFID tags can also contain more product information than a UPC tag; this case study is that the main focus of this comparison. Stanczak (2007) argues that RFID technology is often compared to the UPC code.

To clarify this understanding Stanczak (2007) describes the operation of the RFID system as a wireless technology that uses radio waves to read or "identify" a product/substance that contains a label whose duties are intrinsic operational road information in a specific system.

\section{RFID Tag Attributes}

\begin{tabular}{|c|c|c|}
\hline & Active RFID & Passive RFID \\
\hline Tag Power Source & Internal to tag & $\begin{array}{l}\text { Energy transferted using RF } \\
\text { from reater }\end{array}$ \\
\hline Tag Ealtery & Yes & No \\
\hline Avallability of power & Conteinusus & Only in field of resder \\
\hline $\begin{array}{l}\text { Required signal strength } \\
\text { to Tag }\end{array}$ & Very kow & Very High \\
\hline Range & Loto $100 \mathrm{~m}$ & Up to $3-5 \mathrm{~m}$, usuatly tess \\
\hline Multi-lag reading & $\begin{array}{l}\text { 1000 s } \alpha \text { tage recognized - } \\
\text { wo to } 100 \mathrm{mph}\end{array}$ & $\begin{array}{l}\text { Few numdred seltrin } 3 \mathrm{~m} \text { of } \\
\text { feader }\end{array}$ \\
\hline Data Storage & $\begin{array}{l}\text { Lo to } 128 \mathrm{Ko} \text { or roadwrits } \\
\text { wth sophisticated search } \\
\text { and access }\end{array}$ & 128 cytes of readisnte \\
\hline
\end{tabular}

Figure 2 - System RFID divided into three parts: an antenna, a tag and a reader Source: Stanczak, M. (2007) - RFID Journal (2012).

In Figure 2, above, technology Radio Frequency Identification, or RFID, is usually composed of three parts: an antenna, a tag and a reader. The tag is also called a transponder or device that responds to a specific radar signal / or radio that contains a printed circuit board and / or semiconductor.

The reader is also called a transceiver or transceiver information, and decodes the signal sent by the transponder. Generally, an antenna itself is a tag that generates or obtains energy, in this case radio waves. The tag data is sent out of the system through the antenna, where information is read by the reader / transceiver.

Stanczak (2007) explains that there are two types of RFID tags - active and passive. The passive RFID tags do not use batteries and must be used in a narrow strip of $3 \mathrm{~m}$ or less. That 
is, the antenna must be tuned into a particular radio frequency, and thus send radio waves. Then the player must send a radio signal to the tag / or antenna, which is activated to transmit pertinent information. The radio signal contains enough energy to power the tag, as well as enough time to send your information (Stanczak, 2007).

Most passive RFID tags typically utilize a read-only memory electrically erasable and programmable memory (EEPROM) for small amounts of data, as shown in Figure 3 below.

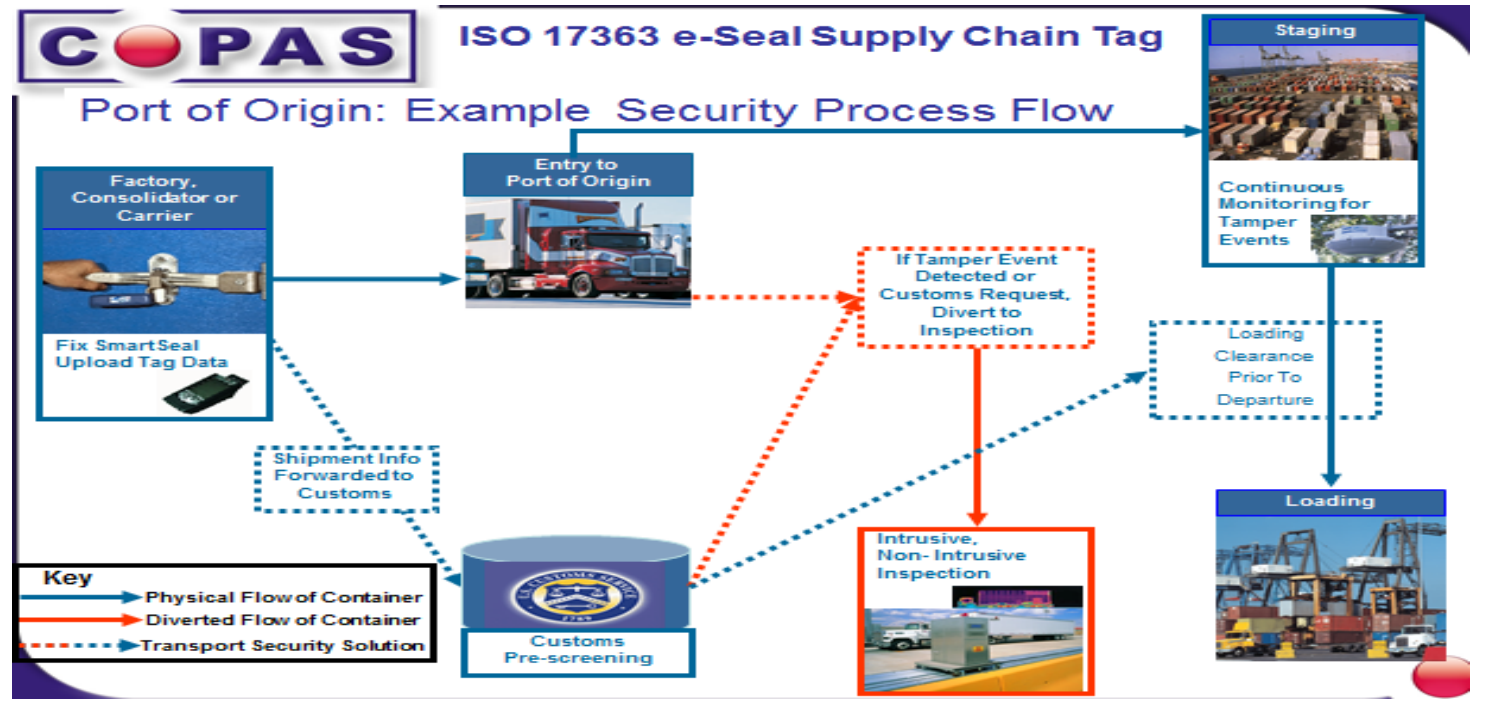

Figure 3 - Attributes of an RFID TAG (2007)

Source: Stanczak, M. (2007)

According Stanczak, (2007) active tags are more sophisticated and therefore more expensive because they use batteries. However, the reader can read tags at a distance of $100 \mathrm{~m}(300 \mathrm{ft})$. Many active tags make use of static random-access memory (SRAM), which means that the information contained in the label is available as long as the tag is powered, for example, by a battery. In summary, an active tag uses an internal power source (battery), while a passive tag uses an external source of energy (radio waves of the reader).

While UPC codes are fairly standardized in a limited way, RFID technology comes in many shapes, sizes and capabilities. The plastic labels found on clothing, in stores, are a familiar example of RFID tags. Other applications of RFID have been innovation of device formats. For example, sub dermal implants are used to identify pets, or endangered shaped devices may be as small as a grain of rice or graphite pencil ( $>10 \mathrm{~mm}$ in length).

Other RFID tags are small enough so they can be built to be embedded in casino chips or be as large as credit cards (Stanczak, 2007). For applications of labels especially large ones such as for reading the contents of railway wagons or containers, an RFID tag can be so large as to measure between 120/100 per $50 \mathrm{~mm}$ (Stanczak, 2007).

Employees and stakeholders tend to observe that in the transportation system there are several elements in interaction and collaboration that are essential for effective deployment of RFID, which greatly fosters new opportunities for engagement of stakeholders in the business. For this reason, all sectors of the logistics should be integrated with appropriate technological resources where RFID can understand essential information for container based on historical logistics are recorded reference numbers or process (BL/DTA/DI/ NF). Above all, there is the 
need to associate and link the control of equipment with logistics management in service to meet the operational needs of the supply chain.

Thus, in order to disseminate information collectors systematically the RFID network supports employment of guards to aid with the inventory of empty containers at depots. According to Machado, Vaz and Sacramento (2012) a solution to reconcile a number of devices on a network of readers who demand a huge amount of RFID data, is the use of an RFID middleware platform. According to Machado, Vaz, Sacramento, (2012) RFID middleware platform can be used with the purpose of integrating RFID data to business processes, the platform being responsible for collecting data from multiple readers and turn them into events so semantics for event business, which means integrating events with the logic that governs the business process of a company.

\section{Operating procedure for collaborative control strategies for RFID}

In the system implanted with RFID, the CIMC alerts are issued on the mobile computer, for example, if a forklift operator or crane grabs the wrong container. The sensors are connected to computers in vehicles through the serial port to help in locating the best access to the court's container yard.

In the factory, passive tags are attached to the container by tape when they leave the assembly line. Labels identify information incorporated in full containers, including the weight, the date and time of manufacture and the customer for which the container is designed. All this information is recorded in the central database of the company. RFID tags are mounted on the windshields of trucks transporting containers from the factory to the stockyard. RFID interrogators are installed at the factory gates, then read the tags on both trucks and containers as they pass the gates, for sending information about the movement to the central database. When the trucks arrive at the container yard, interrogators can digitize both the trailer and the marks of containers, making automatic check-in. Before the pilot project when CIMC containers were ready for transportation from the factory to the storage yard, the truck drivers had to check a huge amount of paperwork to control the gate of the courtyard.

According to RFID JournaL (2012), with the RFID forklifts stacking or discharging containers are equipped with touch screen for on-board computers that run a Mobile Locator and an RFID interrogator, while the mobile computer and the RFID interrogator transmit data through the wireless network. Thus, when a container reaches the place assigned by management, this RFID tag appears on the computer screen mounted on the truck, along with the corresponding information for the identification of container and a three-dimensional map of the terminal.

According to data from the CIMC, the company spent more than U.S. \$ 128,000 in the pilot and continues to save about $\$ 126,000$ U.S. dollars per year as a result of such transactions. Due to this benefit for radio frequency management, the CIMC wants to expand the use of RFID to cut costs in other facilities with similar activities.

\section{METHODOLOGY}

Marconi and Lakatos (2011) and Malhotra (2001, p.106) explain the exploratory research as "a type of research that has as main objective to provide insights about the problem situation faced by the researcher and his understanding." For this purpose, we study a group or community in terms of its structure, emphasizing the interaction of their components (Yin, 2005).

Chizzotti (2005) describing the case study refers to a variety of surveys that collect and record 
data from a particular case or several cases in order to organize an orderly and critical report of an experience, or evaluate it analytically, in order to make decisions about it or propose a transforming action.

The research is exploratory and qualitative. The choice of this methodology aims to seek information in relation to technological innovations globally, although, qualitatively and bounded within the description of the phenomenon investigated. For this insight, we opted for a single case study to substantiate the enclosed form of industrial container in the process of physical distribution of loads.

Marconi and Lakatos (2011) perceive relevant documentary research as that which is does not have relevant scientific treatment, but it shows the problem situation clearly, consisting of information collected at the company that can provide a coherent overview on the problem situation.

Thus, the case study methodology is applied to an associated literature review to compare the results of interviews that favor specific experiences of CPFR by representatives of companies associated with VICS and publications collected by RFID in the RFID Journal.

\section{CASE DEPOT OR CONTAINER YARDS BY MSHIFT CONSULTING}

The innovation to control empty container status with RFID has improved the performance of container terminals, which have depot functions for handling units for picking activities on container yards. Normally, in empty depot containers the operational procedures is started before a container is opened. For example, it should be ensured that it possesses a valid Container Safety Approval Plate and that the re-examination date has not passed. Once this has been established, the following aspects of the container's exterior should be assessed before it is opened or entered.

Based on the technology incorporated in the portable RFID integrated transport system, the technology is applied to provide transparency of the automatic status of the container, in the courtyards of interface criticism. The strategic objectives of the supply chain are defined and established by the portals to generate systemic control. From this initial idea it is possible to accelerate the efficiency of organizational models associated with new technologies, which also incorporate RFID to provide safety and efficacy to the control process.

The call server can act as a location server or standalone system as an add-on to existing system. It includes a business rules processor that allows customers to set their own rules or parameters to maximize operations and workflow. Using this information, the system can create alerts and fix problems or define optimal routes and schedules for moving products between the blocks.

In the case study of benchmarking processes for distribution of empty containers in Brazil, the application of RFID in the transportation system occurs in a DEPOT or empty container yard located in Suzano/SP, which describes ways to identify the management system for the status of container, which is classified in the inspection and data are released virtually or by middleware software, designed to work with RFID.

With respect to the hardware implementation of physical data, information is recorded virtually on tags that are set out in containers. However, one should choose the device carefully as the employee may require different kinds of tags for an effective information system with 
data such as where the containers are inspected and the owner of the transport system, and it may be integrated with a CPFR model with carriers to control demurrages or detention.

Based on RFID, it is possible to describe that after the stored containers, collectors receive the radio frequency signal and so they get the data from the container without physical contact officials. The moment of human participation is unique only when transcribe the status in EIR container is in receipt of the document by the truck driver for data control and inspection of the unit.

In this case, the side lifter container moves between areas and so we opted for the installation of sinks that are deployed on the straps or spreader, whose readers are located in the side lifter cranes and RFID tags, in containers, after the passage of these the gates. Strategic information is collected only once at the time of inspection of container, as they enter the depot where are standardized codes of malfunctions and handling, as well as the historical manufacturing unit mentioned in plate Container Safety Approval Plate.

The data indicate the RFID side lifter equipment operator, the right stack of container or container to collect, due to refueling the offshore sector, in oil and gas platforms.

\section{CONCLUSION}

Based on the pilot project of CIMC it is possible to argue that the benefits of RFID tracking for real-time assets may exceed benefits not fully identified by better inventory visibility, but in the management process. The savings arose for a number of reasons: the number of containers lost in the courtyard of Shenzhen was reduced from four to zero. The rental of forklifts was cut, at peak times, given the speed obtained with the new RFID technology.

In the case study on the enterprise system this dynamic capability associated with customer service is extremely dependent on RFID technology. It is inferred that RFID technology combined with other technological devices such as side lifters can add value to measures that reduce the cost of replacement processes for generating eco-efficiency with integrated solutions for handling the operation of the containers on the backyard.

The RFID provide better management by minimizing handling errors and distribution assets, and concurrently improving the quality of the production process, to reduce the risk of misunderstanding inventory control, every need for physical movement or distribution of empty containers in constant inspection process by the human resources selection process containers in a depot. The use of RFID technologies will enable a framework for enterprises to collaborate, plan monitor and execute, in real-time the extended supply chain management.

The limitation of the study concerns the analysis of a single case study depot container, where it is realized that the field investigation is very broad and has great potential developments.

\section{References}

Albright, B. (2002), “CPFR's secret benefit”, Frontline Solutions, v.3(11):305.

American Heritage Dictionary (2000), 4th ed. In: www.bartleby.com/am. Accessed 18/07/2016.

Barratt, M.; Oliveira, A. (2001), "Exploring the experiences of collaborative planning initiatives", International Journal of Physical Distribution \& Logistics Management, v.31(4):266-89.

Bianco, L.; Toth, P. (1996) Advance Methods in Transport Analysis. Springer.

Chao, C.C., Yang, J.M. Y.; Jen, W.Y. (2007). Determining technology trends and forecasts of RFID by a historical review and bibliometric analysis from 1991 to 2005. Technovation, v. 27(5):268-279. 
Chizzotti , A. (2005). Pesquisa em ciências humanas e sociais.7. ed. São Paulo: Cortez.

CIMC (2012). China International Marine Containers (Group) Ltd. in

http://www.cimc.com/en/about/company/BusinessOverview/. Accessed 23/06/2016.

CNT (2010) Brasília DF. Uma proposta para sua estrutura e Elementos. p.171-190. ANPET. R.J.

CSCMP (2012). Council of Supply Chain Management Professionals. In http://cscmp.org. Accessed 17/05/2016.

Gambom, J. (2006). RFID Contains Solution to Chinese Shipping - Problems. RFID Journal. Eletronic Midia. in http://www.rfidjournal.com/article/articleview/2707/1/655/. Accessed 23/06/2016.

Gonçalves, M. A. (2011) - A racionalidade dos processos de interdependência organizacional em rede. 1. A questão supra-organizacional da interdependência em rede. Cap. 10. p.191-211.

Holmstrom, J., Framling, K., Kaipia, R.; Saranen, J. (2002), “Collaborative planning forecasting and replenishment: new solutions needed for mass collaboration", Supply Chain Management, v.7(3/4):136-45.

Katz, D.; Kahn, R. L. (1974) .Psicologia Social das Organizações. São Paulo: Ed. Atlas.

Machado, B.; Vaz, T.; Sacramento, V. (2012). Midleware RFID: Conceitos e Padrões. In: Implementando RFID na cadeia de negócios. Ed PUCRS. Porto Alegre.

Malhotra, N. (2011). Pesquisa de marketing. Porto Alegre: Bookman.

Manhein, M.D. (1979) Principles of Transport System Analysis. Highway Research Record, n.180.

Marconi, M A.; Lakatos, E.M. (2011). Metodologia científica 6. ed. São Paulo: Atlas.

Morlok, E. K. (1978) Introduction to transportation engineering and planning. MacGraw-Hill, Tokio.

RFID Journal (2006) - China International Marine Containers recently launched an RFID pilot to track containers from its factory to the storage yard. In http://www.rfidjournal.com/article/view/3412. Accessed 23/06/2016.

RFID Journal LLC. (2012):: http://www.rfidjournal.com/glossary/126 .Accessed 18/08/2016

RFID COE (2012). http://www.rfid-coe.com.br/Portugues/CasosDeSucesso.aspx

Stanczak, M. (2007), The ABCs of RFID. CSA Editor: Technology Research Database (TRD); Copper Data Center (CDC). http://www.csa.com/discoveryguides/rfid/editor.php. Accessed 9/06/2016.

Tedesco, G. M.I.; Villella, T.M.A.; Cibulska, P.C.; Ganemann, S. R. (2009) - Procedimentos para a construção da estrutura de sistemas de transporte de cargas. In: Congresso de Pesquisa e Ensino de Transportes -XXII ANPET. Vitória,

Tien-Hsiang C.; Hsin-Pin F., Wan-I L., Yichen L.; Hsu-Chih H. (2007). A study of an augmented CPFR model for the $3 \mathrm{C}$ retail industry. Taiwan. Republic of China. Supply Chain Management: An International Journal. V.12(3):200209.

Van W. A. (2010). Purchasing and Supply Chain Management: analysis, strategy, planning and practice. Hamsphire: Cenage Leaning.

VICS. Voluntary Interindustry Commerce Solutions Association. (2012). VICS Item Level RFID Initiative. Disponível em: http://www.vilri.org/ Accessed em 13/06/2016.

Wanke, P. (2004), Uma revisão dos programas de resposta rápida: ECR, CRP, VMI. CPFR, JIT II. UFRJ, in: http://www.ilos.com.br/web/index.php?option=com content\&view=article\&id=726\%3Aartigos-uma-revisaodos-programas-de-resposta-rapida-ecr-crp-vmi-cpfr-jitii\&catid=4\&Itemid=182\&lang=br. Accessed em 27/06/2016.

WORD SHIPPING COUNCIL - WCS (2012) http://www.worldshipping.org/about-the-industry/containers . Accessed 12/12/2016.

WCS (2012). Guidance Shippers Container Stuffers, in http://www.worldshipping.org/pdf/industry_guidance_shippers_container_stuffers.pdf. Accesed 12/11/2016.

Yin, R. K. (2005), Estudo de Caso: Planejamento e método. 3 ed. Bookman: Porto Alegre.

Houben, A.J.H.M., et al.,(1995). Quantitative analysis of retinal vascular changes in essential and renovascular hypertension. Journal of hypertension. 13(12).

Wasan, B.; Cerutti, A.; Ford, S.; Marsh, R. (1995).Vascular network changes in the retina with age and hypertension. Journal of hypertension. 13(12). 
Koozekanani, D.; Boyer, K. L.; Roberts, C. (2001). Tracking the Optic Nerve Head in OCT Video Using Dual Eigenspaces and an Adaptive Vascular Distribution Model. Computer Vision and Pattern Recognition, IEEE Computer Society Conference. 1:934. 